\title{
Kajian Teologis 1 Petrus 5:7 tentang Perlindungan Allah terhadap Orang Percaya di Tengah Pandemi Covid-19
}

\author{
Joseph Christ Santo1, Yonatan Alex Arifianto² \\ 'Sekolah Tinggi Teologi Berita Hidup, Karanganyar, Indonesia \\ 2Sekolah Tinggi Teologi Sangkakala, Salatiga, Indonesia \\ 1jx.santo@gmail.com,2arifianto.alex@sttsangkakala.ac.id
}

\begin{abstract}
The Covid-19 pandemic has had a very heavy impact on humans to survive. The problem that is felt by all elements of society is related to the economy and the fulfilment of the necessities of life, but also the fear of being exposed to this virus haunts believers. Therefore, governments in affected countries must enact regulations that make the economy's wheels stagnate, as a result, economic problems are a serious problem in the fight against the Coronavirus. This research aims to answer how the concept of protection guarantees for believers is applied in the study of God's word, as a basis and insight to be able to survive and continue the opportunity to live in God's prerogative amidst the threat of the Covid 19 pandemic and the continuing impact that follows. With the formulation of the problem, the literature research method is used with a descriptive qualitative approach. It can be concluded that God's protection is a guarantee of God's providence that occurred in the Old and New Testament times which became the reference for the concept of God's care and protection during the pandemic period to bring believers to become obedient individuals to God by obeying the rules made by the government as a means of maintaining believers.
\end{abstract}

Keywords: Covid-19; God's protection; pandemic

Abstrak. Pandemi Covid-19 telah memberikan dampak yang sangat berat bagi manusia untuk bertahan hidup. Masalah yang dirasakan seluruh elemen masyarakat adalah berkenaan dengan ekonomi dan pemenuhan kebutuhan hidup, tetapi juga rasa kuatir akan terpapar virus ini menghantui orang percaya. Oleh sebab itu pemerintah di negara-negara terpapar harus memberlakukan peraturan yang membuat roda perekonomian tersendat, akibatnya masalah ekonomi menjadi problem yang serius dalam upaya melawan virus Corona. Penelitian ini bertujuan untuk menjawab bagaimana penerapankonsep jaminan perlin-dungan bagi orang percaya dalam kajian firman Tuhan, sebagai dasar dan wawasan untuk dapat bertahan dan melanjutkan kesempatan hidup dalam prerogatif Allah di tengah ancaman pandemi Covid 19 dan dampak berkelanjutan yang mengikutinya. Dengan rumusan masalah tersebut, maka digunakan metode penelitian pustaka dengan pendekatan kualitatif deskriptif. Disimpulkan bahwa God's protection adalah jaminan pemeliharaan Tuhan yang terjadi dalam masa Perjanjian Lama dan Perjanjian Baru yang menjadi acuan konsep pemeliharaan dan proteksi Allah pada masa pandemi untuk membawa orang percaya menjadi pribadi yang taat kepada Tuhan dengan menaati aturan yang dibuat pemerintah sebagai sarana untuk memelihara orang percaya.

Kata kunci: Covid-19; pandemi; pemeliharaan Allah 


\section{PENDAHULUAN}

Pada awal tahun 2020 umat manusia di seluruh dunia diguncang dengan pandemi Virus Corona (Covid-19) yang membuat kepanikan di mana-mana. ${ }^{1}$ Badan Kesehatan dunia atau WHO menjelaskan bahwa Corona viruses (Cov) adalah penyakit menular dari virus yang menginfeksi alat pernapasan. Infeksi virus ini disebut Covid19. Virus Corona menyebabkan penyakit flu biasa sampai penyakit yang lebih parah, dengan merusak fungsi paru-paru menyebabkan gagal nafas pada penderita. Pertama kali wabah ini diketahui adalah kasus klaster pneumonia di Kota Wuhan, Provinsi Hubei, China. ${ }^{2}$ Penyebaran virus Corona ini sangat cepat bahkan sampai melintas benua. Sampai saat tulisan ini dibuat, terdapat 188 negara yang mengonfirmasi terkena wabah virus Corona. Penyebaran dari virus Corona yang telah meluas ke berbagai belahan dunia membawa dampak negatif pada sistem dan tata kelola perekonomian dunia, baik dari sisi perdagangan, investasi dan pariwisata. Sampai saat ini, pemerintah terus bekerja keras dalam memberikan jaminan keamanan dan perlindungan kesehatan dari pandemi Corona Virus atau Covid-19.

Dalam rangka memberikan perhatian dan jaminan tersebut, pemerintah terus berupaya mengurangi jumlah kelompok terinfeksi dengan perlindungan berupa pengawasan terhadap orang yang terinfeksi, kerja keras untuk penemuan dini atas kasus-kasus baru guna menekan laju penularan, dan perlindungan terhadap petugas kesehatan. Namun sejauh ini angka kematian dan suspek dari virus ini tetap tinggi. Walaupun berita baiknya banyak juga pasien akibat virus ini dinyatakan sembuh, tidak menutup kemungkinan bahwa virus ini membawa pengaruh lain bagi manusia dengan ketakutan dan kekhawatiran. Ini merupakan dampak buruk dari realitas penularan yang terus dihembuskan media. Selain kekhawatiran akan jaminan kesehatan, wabah Covid-19 juga berdampak pada konflik kepentingan, dan yang sangat terasa adalah dampak sosial, di mana manusia menjadi saling menjauh dan takut akan interaksi sosial. Bahkan indikasi penolakan jenazah Covid-19 pada pemakaman umum di beberapa daerah, menunjukkan rasa kemanusiaan yang menjadi berkurang, baik terhadap yang masih hidup maupun yang sudah meninggal. Wabah covid-19 merupakan bencana non-alam yang tidak saja berkaitan dengan masalah kesehatan semata, tetapi juga memiliki keterkaitannya dengan masalah ekonomi, psikososial dan bahkan sosial politik. ${ }^{3}$

Di Indonesia terus meningkatnya jumlah penderita Covid-19 mengakibatkan kontraksi pertumbuhan ekonomi. Laju pertumbuhan ekonomi saat pandemi Covid-19 tentu saja mengalami penurunan. ${ }^{4}$ Selain itu juga peningkatan jumlah pengangguran

\footnotetext{
${ }^{1}$ Dana Riksa Buana, "Analisis Perilaku Masyarakat Indonesia Dalam Menghadapi Pandemi Virus Corona (Covid-19) Dan Kiat Menjaga Kesejahteraan Jiwa," SALAM: Jurnal Sosial dan Budaya Syar-i 7, no. 3 (2020).

${ }^{2}$ Kementerian Kesehatan Republik Indonesia, "Pedoman Kesiapsiagaan Menghadapi Coronavirus Disease (COVID-19)," Direkorat Jenderal Pencegahan dan Pengendalian Penyakit (2020).

${ }^{3}$ Max Regus and Marianus M. Tapung, "Penanganan Covid-19 Dalam Semangat Diakonia Gereja Keuskupan Ruteng: Sebuah Lapoan PKM," BERDAYA: Jurnal Pendidikan dan Pengabdian Kepada Masyarakat 2, no. 2 (2020): 41-52.

${ }^{4}$ Anak Agung Manik Pratiwi, "Peran Media Sosial Dalam Meningkatkan Penjualan Online Saat
} 
yang signifikan. ${ }^{5}$ Penurunan pendapatan dari unsur-unsur masyarakat tersebut akan menciptakan lapisan masyarakat yang sangat rentan terkena dampak Covid-19, baik secara medis, ekonomi, maupun sosial. Mereka yang tergolong dalam ekonomi lemah semakin besar imbasnya. ${ }^{6}$ Memang dampak negatif dari virus Covid-19 melanda banyak negara di dunia termasuk Indonesia. Wabah Covid-19 tidak hanya merupakan masalah nasional dalam suatu negara, tapi sudah merupakan masalah global. ${ }^{7}$ Bahkan saat ini perekonomian dunia mengalami tekanan berat yang diakibatkan oleh virus tersebut. 8

Selain kerugian materi maupun hubungan sosial, ada juga kerugian akibat Covid-19 ini akibat adanya penyebaran berita hoaks kepada masyarakat. Dampak yang terjadi karena berita hoaks ini adalah kekhawatiran, kesalahpahaman, kegaduhan, sehingga masyarakat banyak yang dirugikan, sebab berita hoaks pembodohan bagi yang mengonsumsinya. Berita hoaks yang disebarkan adalah cara untuk pengalihan isu, pemecah belah, penipuan publik yang dilakukan oleh orang yang tidak bertanggung jawab. ${ }^{9}$ Dengan media sosial tersebarnya berita hoaks berlangsung turut menebarkan nilai-nilai negatif. ${ }^{10}$ Akibatnya hampir seluruh masyarakat di dunia saat ini merasakan kekhawatiran dan kegelisahan yang mendalam. ${ }^{11}$

Masalah yang dirasakan seluruh elemen masyarakat adalah berkenaan dengan ekonomi dan segala kebutuhan hidup. Oleh sebab itu pemerintah di negara-negara terpapar untuk memberlakukan peraturan yang membuat roda perekonomian tidak tersendat. Pemerintah-pemerintah di seluruh dunia mengeluarkan dana yang sangat besar untuk mengatasi pandemi Covid-19, sementara itu banyak masyarakat penghasilannya mulai berkurang, bahkan mengalami Pemutusan Hubungan Kerja (PHK). ${ }^{12}$ Pembatasan aktivitas akibat pandemi Covid-19 juga telah menimbulkan kerugian ekonomi secara nasional. Kerugian itu hanya akan tertutupi apabila krisis dapat diakhiri sebelum menimbulkan kebangkrutan usaha secara massal. ${ }^{13}$ Dampak domino dari Covid-19 ini juga mengubah peta perdagangan dunia, selain mengakibatkan

Pandemi Covid-19,” Jurnal Ilmiah Satyagraha 3, no. 2 (2020): 73-81.

${ }^{5}$ Rahma Ainul Mardiya dan R. Nunung Nurwati, "Dampak Pandemi Covid-19 Terhadap Peningkatan Angka Pengangguran Di Indonesia," Rahma Ainul Mardiyah R. Nunung Nurwati (2020).

${ }^{6}$ Putu Agung Nara Indra Prima Satya, "Covid- 19 Dan Potensi Konflik Sosial," Jurnal Ilmiah Hubungan Internasional 0, no. 0 (2020): 39-45.

${ }^{7}$ Syafrida Syafrida and Ralang Hartati, "Bersama Melawan Virus Covid 19 Di Indonesia," SALAM: Jurnal Sosial dan Budaya Syar-i 7, no. 6 (2020): 495-508.

${ }^{8}$ Chairul Baharudin, Iksan and Muhammad Abdi, Nur, "Ancaman Krisis Ekonomi Global Dari Dampak Penyebaran Virus Corona (Covid-19)," AkMen Jurnal Ilmiah (2020).

${ }^{9}$ Nabila Farahdila Putri, Ellin Vionia, and Tomy Michael, "Masyarakat Indonesia Menghadapi Penyebaran Berita Hoax Covid-19," Jurnal Ilmu Hukum 11, no. 1 (2020): 98-111.

${ }^{10}$ Engkos Kosasih et al., "Literasi Media Sosial Dalam Pemasyarakatan Moderasi Beragama Dalam Situasi Pandemi Covid-19," Digital Library UIN Sunan Gunung Djati Bandung (2020).

${ }^{11}$ Adida Casriarno and Demianus Nataniel, "Dinamika Pendidikan Agama Kristen Di Tengah Wabah Corona: Sebuah Refleksi Berdasarkan Pengajaran Paulus Dalam Galatia 6:2," Jurnal Abdiel: Khazanah Pemikiran Teologi, Pendidikan Agama Kristen, dan Musik Gereja 4, no. 1 (2020): 25-42.

${ }^{12}$ Ibid.

${ }^{13}$ Wibowo Hadiwardoyo, "Kerugian Ekonomi Nasional Akibat Pandemi Covid-19," Baskara Journal of Business and Enterpreneurship 2, no. 2 (2020): 83-92, https://jurnal.umj.ac.id/index.php/baskara/article/view/6207. 
mandegnya berbagai bidang usaha. Kinerja perdagangan global dipastikan akan terganggu. ${ }^{14}$ Tidak hanya jutaan jumlah korban yang terinfeksi Covid-19 tetapi turut menyumbang angka kematian jiwa manusia yang tidak sedikit, juga berbagai sektor pun turut merasakan dampak mengerikan dari pandemi ini, sosial, keamanan, dan terkhusus sektor perekonomian yang sangat merugikan banyak pihak. ${ }^{15}$ Hal itu menyebabkan pada masa pandemi Covid-19 ini banyak orang menjadi kuatir akan masalah kehidupannya, ${ }^{16}$ baik kebutuhan jasmani maupun kebutuhan rohani yang di mana aktivitas gereja dan peribadatan juga dibatasi supaya penyebaran virus Covid-19 tidak menyebar luas. Jelas Situasi dan kondisi yang menakutkan akibat penyakit ini sangat memukul dunia dan seluruh penduduknya mengalami kekhawatiran dan kegelisahan bahkan putus asa dalam menjalani kehidupan. ${ }^{17}$

Dari persoalan dan permasalahan yang dihadapi bangsa, khususnya orang percaya, akibat pandemi ini, peneliti ingin menjawab bagaimana sikap orang Kristen dalam menghadapi kekhawatiran dan mendeskripsikan penerapan konsep jaminan perlindungan bagi orang percaya dalam kajian firman Tuhan dalam 1 Petrus 5:7 sebagai dasar dan wawasan untuk dapat bertahan dan melanjutkan kesempatan hidup dalam prerogatif Allah di tengah ancaman pandemi Covid 19 dan dampak berkelanjutan yang mengikutinya.

\section{METODE}

Untuk menjawab pertanyaan bagaimana penerapan konsep jaminan perlindungan dari Tuhan bagi orang percaya, penulis menggunakan metode penelitian pustaka dengan pendekatan kualitatif deskriptif,18 yang mengeksegesis data-data dari teks ayat 1 Petrus 5:7 tersebut serta menuangkannya dalam penggalian Alkitab tentang peran Tuhan bagi orang percaya di tengah wabah korona. Setelah terumuskan konsep tersebut maka dijelaskan secara deskriptif dan kemudian diuraikan secara singkat bagaimana konsep perlindungan Allah sesuai Alkitab. Maka itu dengan menggunakan Alkitab terkhusus dalam 1 Petrus 5:7 sebagai sumber primer dan secara pararel ditemukan ayat-ayat yang memuat kata-kata yang diinginkan oleh tema tersebut. Kemudian setiap kata yang berhubungan ditelusuri dengan buku-buku terbaru dan terbitan jurnal untuk menambah sumber dalam penelitian pustaka ini. Dari makna literal maupun makna kontekstual, maka dapat disusun kajian yang dapat dituangkan secara deskriptif.

\footnotetext{
${ }^{14}$ Yusep Mulyana, "Peranan Ekonomi Pembangunan Pasca Covid 19," PRISMAKOM Sekolah Tinggi Ilmu Ekonomi Yasa Anggana Garut 17, no. 1 (2020): 37-45.

${ }^{15}$ Debby Christ Mondolu and Obet Nego, "Covid-19: Wabah Alkitabiah, Relevankah?," SCRIPTA: Jurnal Teologi dan Pelayanan Kontekstual 9, no. 1 (2020): 32-51.

${ }^{16}$ Sri Wahyuni Kusradi, "Kasih Setia Tuhan Dalam Perjanjian Lama Dan Relevansinya Bagi Orang Percaya Pada Masa Covid-19," SCRIPTA: Jurnal Teologi dan Pelayanan Kontekstual 9, no. 1 (2020): 5371, https://ejournal.stte.ac.id/index.php/scripta/article/view/112.

${ }^{17}$ Yonatan Alex Arifianto, "Pentingnya Pendidikan Kristen Dalam Membangun Kerohanian Keluarga Di Masa Pandemi Covid-19," Regula Fidei Jurnal Pendidikan Agama Kristen 5, no. 2 (2020): 94-106.

${ }^{18}$ Sonny Eli Zaluchu, "Strategi Penelitian Kualitatif Dan Kuantitatif Di Dalam Penelitian Agama," Evangelikal: Jurnal Teologi Injili dan Pembinaan Warga Jemaat 4, no. 1 (2020): 28.
} 


\section{HASIL DAN PEMBAHASAN}

Pandemi Covid-19 telah melanda dunia termasuk Indonesia, sehingga program stay at home dilaksanakan sebagai upaya menekan penyebaran Covid-19.19 Pandemi telah menimbulkan masalah sosial dan pelemahan ekonomi masyarakat dan negara. ${ }^{20}$ Pandemi juga berdampak pada kehidupan sosial manusia, baik segi psikologi maupun perilaku manusia ${ }^{21}$, karena kebiasaan-kebiasaan berkomunikasi dan berinteraksi satu sama lain dengan bertemu fisik tidak lagi menjadi penting dan utama pada saat ini. Komunikasi dan interaksi juga dianjurkan dengan cara yang aman yaitu bertemu dalam dunia maya atau disebut virtual. ${ }^{22}$ Bahkan ibadah yang merupakan bagian dari keyakinan pribadi juga harus diatur lewat pembatasan berkerumun. Pemerintah sudah mengeluarkan aturan yang menganjurkan agar umat beragama beribadah di rumah saja (Peraturan Pemerintah Nomor 21 Tahun 2020 tentang pembatasan sosial berskala besar dalam rangka percepatan penanganan Corona Virus Disease 2019. Hal ini untuk mencegah penyebaran Covid-19, terutama untuk daerah zona merah yang sedang menerapkan PSBB. Setiap umat beragama diharuskan menjalankan ibadah di rumahnya masing-masing. Kegiatan ibadah di rumah ini didukung surat edaran dari Kementerian Agama RI untuk mencegah penularan Covid-19. Namun, pada tanggal 26 Mei 2020, Kementerian Agama (Kemenag) sudah mengeluarkan Surat Edaran Nomor 15 Tahun 2020 untuk penyelenggaraan keagamaan di rumah ibadah dalam rangka menuju masyarakat produktif dan aman dari wabah Covid-19.

Demi pencegahan penyebaran Covid-19, secara khusus WHO memberikan masukan dan anjuran yang tepat untuk menghentikan sementara kegiatan-kegiatan yang berpotensi menimbulkan bertemunya kerumunan massa. ${ }^{23}$ Negara Indonesia melaksanakan konsep karantina dan social distancing yang di satu sisi dapat menekan dan menghambat penyebaran virus Covid-19 seperti yang dialami oleh China dan Korea Selatan. Namun, kebijakan ini juga menyimpan konsekuensi yang tidak kalah menyakitkan, sebab kedua metode tersebut dapat menghambat bahkan mematikan perekonomian di wilayah-wilayah yang menerapkan kebijakan ini. Akhirnya, jika tidak dikelola dengan persiapan yang memadai, kebijakan ini berpotensi memicu timbulnya konflik sosial. ${ }^{24}$ Pemerintah juga bekerja keras untuk mengutamakan kesehatan dengan memelihara tubuh agar sehat sebab pemeliharaan terhadap tubuh bermakna "penjagaan jiwa". Jiwa yang sehat terdapat dalam tubuh yang sehat (men-

\footnotetext{
${ }^{19}$ Dian Ratu Ayu Uswatun Khasanah, Hascaryo Pramudibyanto, and Barokah Widuroyekti, “Pendidikan Dalam Masa Pandemi Covid-19," Jurnal Sinestesia 10, no. 1 (2020): 41-48, https://sinestesia.pustaka.my.id/journal/article/view/44.

${ }^{20}$ Syafrida and Hartati, "Bersama Melawan Virus Covid 19 Di Indonesia."

${ }^{21}$ Ivan Muhammad Agung, "Memahami Pandemi Covid-19 Dalam Perspektif Psikologi Sosial," Psikobuletin:Buletin Ilmiah Psikologi 1, no. 2 (2020): 68-84, http://ejournal.uinsuska.ac.id/index.php/Psikobuletin/article/view/9616/5058.

${ }^{22}$ Basthoumi Muslih, "Urgensi Komunikasi Dalam Menumbuhkan Motivasi Di Era Pandemi Covid-19," 58 Jurnal Penelitian Manajemen Terapan (PENATARAN) Vol. 5, no. 1 (2020): 57-65.

${ }^{23}$ Kosasih et al., "Literasi Media Sosial Dalam Pemasyarakatan Moderasi Beragama Dalam Situasi Pandemi Covid-19."

${ }^{24}$ Satya, "Covid- 19 Dan Potensi Konflik Sosial."
} 
sana in corpore sano). ${ }^{25}$

Pandemi Covid-19 yang belum jelas arah pengobatannya berdampak pada sikap dan perilaku manusia menjadi kuatir dan pesimis akan pemeliharaan Tuhan. sebab kehadiran Covid-19 ini telah menjadi momok tersendiri bagi peradaban manusia di era milenial ini. ${ }^{26}$ Namun kekristenan diharapkan mampu memberikan jawaban terhadap kegelisahan manusia, seperti yang dinyatakan Petrus dalam Suratnya bahwa ada pemeliharaan Tuhan bagi orang percaya (1 Pet. 5:7). Untuk memberikan pemahaman terhadap penulis

\section{Eksegesis 1 Petrus 5:7}

Di dalam 1 Peter 5:7 dituliskan, "Serahkanlah segala kekuatiranmu kepada-Nya, sebab Ia yang memelihara kamu." Teks 1 Peter 5:7 dalam bahasa Yunani berbunyi,

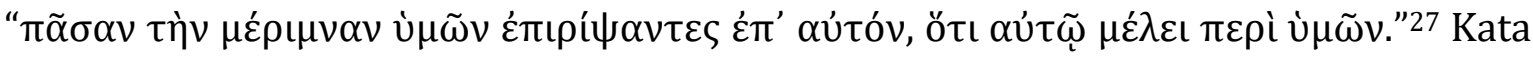
$\pi \tilde{\alpha} \sigma \alpha \nu$ (pasan) adalah adjektif akusatif feminin tunggal, dengan arti setiap jenis,

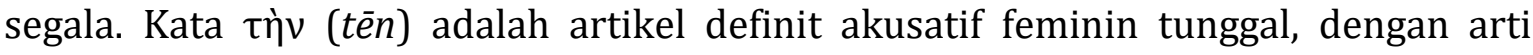
fungsi membatasi kata benda yang mengikutinya. Kata $\mu \varepsilon \dot{\rho} \mu \nu \alpha \nu$ (merimnan) adalah kata benda akusatif feminin tunggal umum dengan arti kecemasan, kekhawatiran; sebagai bentuk rasa yang belum terjadi namun ada. ${ }^{28}$ Kata $\dot{u} \mu \tilde{\omega} \nu$ (humon) adalah kata

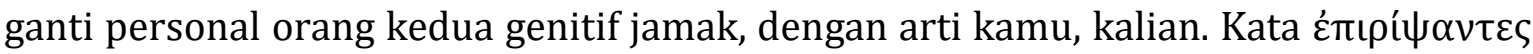
(epiripsantes) adalah kata kerja partisipel aoris aktif nominatif maskulin jamak, dengan arti menyerahkan, melemparkan, melepaskan. Kata ć一兀' ( $e p^{\prime}$ ) berasal dari kata غ́лı (epi) merupakan kata depan akusatif, yang berarti ke atas atau kepada. Kata

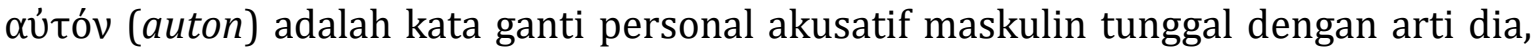
yang berhubungan langsung dengan kata 'śn' ( $e p^{\prime}$ ) yang mendahuluinya; sehingga frasa ini berarti kepada dia. Kata ǒ $\tau$ (hoti) adalah kata sambung subordinasi dengan

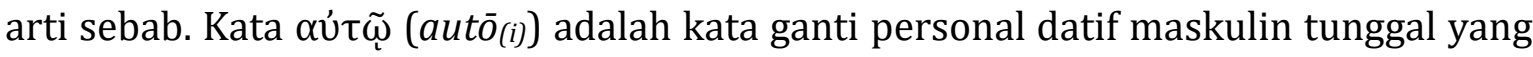
berarti dia. Kata $\mu \varepsilon ́ \lambda \varepsilon \iota$ (melei) adalah kata kerja indikatif kini aktif orang ketiga

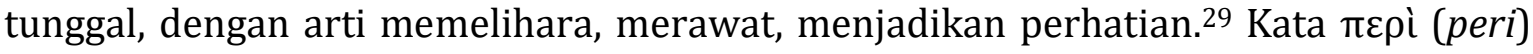
adalah kata depan genitif dengan arti tentang atau mengenai. Kata ù $\mu \tilde{\omega} \nu$ (humōn) adalah kata ganti personal genitif jamak dengan arti kamu atau kalian. ${ }^{30}$

Dari eksegesis didapat pernyataan Petrus tentang menyerahkan kekhawatiran,

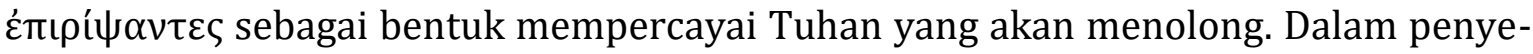
rahan tersebut tidak lupa bahwa ada Tuhan yang memberikan perhatian dari segala keadaan yang datang kepada orang percaya, dan bahwa Tuhan sanggup memelihara. Dari hasil tersebut didapat antara lain:

\section{Menyerahkan Kekhawatiran}

"Serahkanlah segala kekuatiranmu kepada-Nya, sebab Ia yang memelihara ka-

\footnotetext{
${ }^{25}$ Regus and Tapung, "Penanganan Covid-19 Dalam Semangat Diakonia Gereja Keuskupan Ruteng: Sebuah Lapoan PKM.”

${ }^{26}$ Mondolu and Nego, "Covid-19: Wabah Alkitabiah, Relevankah?”

${ }^{27}$ BibleWorks ceased operation as a provider of Bibleworks, "BibleWorks," 2018.

${ }^{28}$ B.F. Drewes, Wilfrid Haubeck, and Siebenthal Heinrich Von, Kunci Bahasa Yunani Perjanjian Baru Surat Roma Hingga Kitab Wahyu, (Jakarta: BPK Gunung Mulia, 2011), 332.

${ }^{29}$ Ibid.

${ }^{30}$ Bibleworks, "BibleWorks."
} 
mu" (ay. 7). Kata "serahkanlah", dari kata Yunani ćmıрí $\tau \omega$ (epiriptō), artinya melemparkan, menyerahkan. Partisipel bentuk aoris (lampau) menunjukkan suatu tindakan sekali untuk selamanya; melemparkan seluruh kehidupan dengan segala kekhawatirannya kepada-Nya. ${ }^{31}$ Kekhawatiran dan rasa takut yang besar di dalam diri timbul karena kesukaran-kesukaran yang mungkin akan terjadi dan akibatnya bagi diri mereka, keluarga mereka, dan jemaat Allah. ${ }^{32}$ Penawar terbaik untuk menghadapi kekhawatiran yang berlebihan ialah dengan menyerahkan segala kekhawatiran kita kepada Allah, dan menyerahkan segala peristiwa (bukan fatalis yang tidak berusaha apa pun) kepada pengaturan yang penuh hikmat dan penuh kasih karunia. ${ }^{33}$ Kekhawatiran adalah "rasa takut tentang sesuatu hal yang belum pasti terjadi; merasa cemas; atau merasa gelisah". Kekhawatiran hadir pertama kali dalam kehidupan manusia sebagai akibat dosa. Kekhawatiran merupakan dampak dari kejatuhan manusia pertama (Adam dan Hawa) dalam dosa. ${ }^{34}$ Menyerahkan kekhawatiran dimulai dari pribadi yang menghidupi kerendahan hati dan hidup tenang, ${ }^{35}$ karena kerendahan hati dapat membawa peninggian dari Tuhan. ${ }^{36}$ Penyerahan diri kepada Tuhan menjadi prioritas pertama sebagai bagian kehidupan orang percaya dalam menjalani kehidupan yang menakutkan dan mencemaskan ini.

\section{Jaminan Pemeliharaan Tuhan}

Kekristenan mengajar penganutnya untuk tetap percaya dan mengandalkan Tuhan dalam segala lini kehidupan. Banyak sekali firman Allah dalam Alkitab yang menjadi jawaban dari segala persoalan manusia, dan dengan adanya jaminan pemeliharaan Tuhan diharapkan hidup manusia bebas dari berbagai kecemasan dan kekhawatiran. ${ }^{37}$

Sejak Allah menciptakan alam semesta, segala makhluk tetap bergantung kepada-Nya setiap saat. Oleh karena itu tidak ada sesuatu di dalam dunia ini yang berdiri sendiri, lepas daripada Allah. Pemeliharaan Allah dihubungkan dengan tetap beradanya segala sesuatu yang telah diciptakan, sedang pemerintahan Allah dihubungkan dengan tujuan ke mana dunia ini akan dipimpin Allah. ${ }^{38}$ Hadiwiyono mengatakan bahwa pemeliharaan Tuhan, yaitu karya-Nya untuk melangsungkan adanya dunia, haruslah dibedakan dengan karya-Nya untuk menciptakan dunia. Karya penciptaan adalah karya untuk menjadikan hal-hal yang semula belum ada menjadi ada. Akan

\footnotetext{
${ }^{31}$ Hasan Susanto, Konkordansi Pejanjian Baru Interlinear Yunani-Indonesia, (Jakarta: Lembaga Alkitab Indonesia, 2004), 305.

${ }^{32}$ Henry's Matthew, "Matthew Henry Commentary On Whole Bible," 2002, https://www.biblestudytools.com/commentaries/matthew-henry-complete/1 Petrus/2.html.

${ }^{33}$ Hanok Tuhumury, "Pelayanan Pastoral Konseling Berdasarkan 1 Petrus 5:1-11," Missio Ecclesiae 7, no. 1 (2018): 68-100.

${ }^{34}$ Kerdi Bancin, "NASEHAT TENTANG KEKUATIRAN STUDI EKSEGETIS MATIUS 6: 25-34 DAN REFLEKSINYA PADA KEHIDUPAN UMAT KRISTEN MASA KINI," Areopagus: Jurnal Pendidikan Dan Teologi Kristen 18, no. 2 (2020): 161-169.

35 "The Wycliffe Bible Commentary," Biblestudytoolscom, last modified 2014, accessed June 30, 2020, https://www.biblestudytools.com/wyc/.

${ }^{36}$ Wilkinson Bruce and Boa kenneth, The Talk Thru Bible (Malang: Gandum Mas, 2017), 580.

${ }^{37}$ Darminta SJ, Peziarahan Keluarga (Yogyakarta: kanisius, 2006), 35.

${ }^{38}$ Harun Hadiwijono, Iman Kristen (Jakarta: BPK Gunung Mulia, 2007), 213.
} 
tetapi karya pemeliharaan Tuhan Allah adalah karya-Nya untuk melangsungkan apa yang telah diciptakan tadi, supaya tetap berada. ${ }^{39}$ Selaras dengan keinginan Tuhan dalam memelihara manusia dan semua yang diciptakan, maka membicarakan hal pemeliharaan Allah tidak pernah lepas dari karya pemerintahan-Nya atas dunia. ${ }^{40}$ Karena Allahlah yang memelihara segala makhluk ciptaan-Nya (Neh. 9:6), dengan memberikan makanan (Mzm. 136:5), Allah juga memelihara dan mengatur segala sesuatu untuk keberlangsungan dunia dan alam semesta (Kej. 8:22). Dikatakan bahwa Allah Israel selalu aktif menjaga (Mzm. 121:4), walaupun pemeliharaan-Nya tidak dapat dipahami manusia dan merupakan hal yang rahasia (Roma 11:33).

Berdasarkan sejarah perjalanan kehidupan yang Allah mulai sejak penciptaan, masuk dalam Perjanjian Lama, munculnya kekristenan, sampai kepada para bapa gereja, orang Kristen meyakini bahwa Allah memelihara dan memerintah bumi. Alkitab mengatakan bahwa Tuhan mengatur dan memiliki ketetapan (Yes. 46:9-10; Ef. 1:11; Rm. 9:15, 16, 18). Tidak satu pun peristiwa yang terjadi di dunia tanpa seizin-Nya (Kis. 2:23). Dalam pemeliharaan yang Allah lakukan, ada tiga aspek pemeliharaan Allah yaitu: Pertama, aspek pelestarian. Dengan kuasa-Nya Allah melestarikan dunia yang diciptakan-Nya. Kedua, penyediaan. Allah bukan saja melestarikan bumi yang diciptakan-Nya, tetapi Ia juga menyediakan apa yang diperlukan oleh ciptaan-Nya itu. Yesus mengungkapkan dengan tegas dan jelas bahwa Allah menyediakan memberi perlindungan dan memelihara serta merawat burung-burung di udara dan bunga-bunga bakung di padang (Mat. 6:26-30; 10:29).

Pemeliharaan-Nya menyediakan bukan saja kebutuhan jasmaniah yaitu pangan, papan, sandang manusia, tetapi juga kebutuhan rohaninya untuk terus terhubung dengan Tuhan (Yoh. 3:16-17). Alkitab menyatakan bahwa Allah sangat jelas menunjukkan kasih, anugerah, dan perhatian khusus bagi umat-Nya. Masing-masing pribadi dihargai-Nya dan dihormati, karena Allah menciptakan manusia dengan free will (Mzm. 91:1-16). Ketiga, adalah pemerintahan. Di samping Allah melakukan pelestarian dan penyediaan kebutuhan segala ciptaan-Nya, Ia juga memerintah dunia ini dan sejatinya Allah berdaulat, karena segala peristiwa-peristiwa dalam sejarah terjadi menurut kehendak-Nya yang mengizinkan dan pengawasan-Nya. ${ }^{41}$

\section{Konsep Pemeliharaan dan Proteksi Allah dalam Penderitaan}

Penyataan alkitabiah menunjukkan bahwa pemeliharaan atau proteksi Allah bukan sebuah doktrin semu atau hal yang tidak pasti tetapi pemeliharaan Tuhan itu ada dan berlaku untuk kehidupan keseharian di dalam dunia yang jahat dan berdosa ini. ${ }^{42}$ Namun saat ini umat manusia di seluruh dunia diperhadapkan dengan wabah virus Corona dan keadaan terkini kondisi yang mengejutkan dan meluluhlantakkan berbagai sendi kehidupan. Bukan hanya kekhawatiran akan penderitaan fisik yang diakibatkan oleh Covid-19, namun juga seluruh aspek kehidupan politik, ekonomi,

39 Ibid.

${ }^{40}$ Ibid.

${ }^{41}$ Alkitab Sabda, "Pemeliharaan Allah," Yayasan Lembaga SABDA (YLSA), last modified 2005,

accessed September 23, 2020, https://alkitab.sabda.org/article.php?id=8404.

42 Ibid. 
sosial, hingga religiositas dan spiritualitas manusia menjadi terganggu. ${ }^{43}$ Terlebih berkaitan dengan persoalan yang terjadi pada saat ini, dampak blow up dan hoaks tentang pandemi Covid-19 yang sering kali membenturkan iman percaya manusia dengan keadaan sebenarnya yang terjadi atas manusia sebagai bagian dari rencana Tuhan yang tidak pernah gagal. Kelangsungan akan keberadaan dalam dunia, yang disebabkan karena karya pemeliharaan Tuhan Allah itu, dihubungkan dengan maksud Allah agar manusia menjadi pribadi yang mengasihi umat-Nya. ${ }^{44}$ Namun jaminan Allah juga mengizinkan setiap orang mengalami penderitaan seperti yang dinyatakan dalam 1 Korintus 10:13, bahwa setiap pencobaan yang diizinkan terjadi, pasti ada solusinya. Sebab setiap persoalan yang diizinkan Tuhan tidak akan melebihi kekuatan manusia dan Tuhan meyakinkan dengan solusi atau jalan keluar yang dapat memberikan ketenangan dan damai sejahtera.

Fakta yang terjadi, keadaan wabah Corona-19 seolah-olah tidak memandang bulu. Realitasnya banyak anak Tuhan atau pelayan Tuhan juga terdampak, dan berakhir pada kematian. ${ }^{45}$ Memang hal itu adalah hak dan prerogatif Allah dalam keadilan dan kekuasaan-Nya atas manusia. Kematian bagi kekristenan bukan hal yang memalukan namun kematian bagi kekristenan, seperti yang diungkapkan rasul Paulus, adalah keuntungan (Flp. 1: 21-22). Kematian pasti terjadi bagi semua orang namun rasul Paulus ingin membawa jemaat Filipi lebih bisa memandang realitas kehidupan ini dengan siap dan tidak usah panik lagi dengan masalah-masalah yang muncul dan yang akan muncul ketika menjalani kehidupan ini. ${ }^{46}$ Paulus sendiri tidak terlalu mempermasalahkan antara hidup atau mati, karena (baik hidup atau mati) Kristus adalah keuntungan. Inilah kestabilan iman seorang yang mengikut dan melayani Kristus, yaitu ia tidak terbuai oleh kehidupan sekarang dan sekaligus tidak dihantui oleh "momok" kematian yang ada di depannya, "Sebab jika kita hidup, kita hidup untuk Tuhan, dan jika kita mati, kita mati untuk Tuhan. Jadi baik hidup atau mati, kita adalah milik Tuhan" (Rm. 14:8). Dengan demikian, sekalipun kematian tetap merupakan sebuah ancaman, mendatangkan ketakutan, dan setara dengan malapetaka yang mengerikan, kestabilan iman orang percaya yang memiliki dan dimiliki oleh Kristus yang mengendalikan kehidupannya sekarang ini. ${ }^{47}$ Demikian pula orang percaya ketika kematian datang memiliki pemahaman yang kuat bahwa kematiannya berharga di hadapan Allah. Seperti yang ditulis oleh pemazmur "Berharga di mata Tuhan kematian semua orang yang dikasihi-Nya.” (Mzm. 116:15).

Jika Tuhan mengizinkan orang percaya masuk dalam penderitaan seperti saat

\footnotetext{
${ }^{43}$ David Alinurdin, “COVID-19 Dan Tumit Achilles Iman Kristen,” Veritas: Jurnal Teologi dan Pelayanan 19, no. 1 (2020): 1-9.

${ }^{44}$ Hadiwijono, Iman Kristen, 215.

${ }^{45}$ Whisnu Pradana, "Positif Corona Juga, Istri Pendeta Meninggal Di RSHS Bandung," DetikNews Berita Jawa Barat, last modified 2020, accessed September 22, 2020, https://news.detik.com/beritajawa-barat/d-4956105/positif-corona-juga-istri-pendeta-meninggal-di-rshs-bandung.

${ }^{46}$ Romianna Magdalena Sitompul, "Makna Perkataan Paulus Tentang Hidup Adalah Kristus Dan Mati Adalah Keuntungan Berdasarkan Filipi 1:12-26," Jurnal Jaffray 15, no. 2 (2017): 153.

${ }^{47}$ Daniel L. Lukito, "Iman Kristen Di Tengah Pandemi: Hidup Realistis Ketika Penderitaan Dan Kematian Merebak” (LP2M STT SAAT, 2020), 12.
} 
ini pasti Allah memberi kekuatan untuk menanggung penderitaannya berdasarkan kesadaran bahwa Kristus pun mengalami hal yang serupa dan berhasil menang atas penderitaan tersebut. ${ }^{48}$ Itu adalah solusi dari Allah bagi manusia dan pasti Allah memiliki rencana kepada setiap manusia yang diizinkan melalui pandemi Covid-19 ini. Sebagian orang dapat menerima penderitaannya dan menjadi semakin beriman saat diuji dalam penderitaan, sementara sebagian yang lain tidak dapat menerimanya dan kehilangan iman. Bagi orang yang tidak dapat menerima penderitaan hidupnya, Allah yang Mahakasih dianggap sebagai semacam konsep tipuan atau khayalan, sehingga kurang diimani, karena dianggap tidak membantu. ${ }^{49}$ Padahal dalam Kekristenan, iman merupakan hal yang sangat esensial dan mutlak bagi orang percaya. ${ }^{50}$ Dalam penghayatan hidup orang Kristen, iman diperlukan saat menghadapi penderitaan, terutama yang dialami orang-orang saleh. Tidak heran hal tersebut menimbulkan pertanyaan besar atas konsep Allah yang Mahaadil, Maha-kasih, dan Mahakuasa. Orang bertanya-tanya mengapa penderitaan juga terjadi atas seseorang yang tidak pernah berbuat jahat terhadap sesamanya, dan mengapa Allah tidak menolong dengan segera. ${ }^{51} \mathrm{Hal}$ ini dapat saja terjadi karena manusia tidak mematuhi keinginan Tuhan yang tertuang dalam peran pemerintah mengatur proto-kol kesehatan.

Masalah-masalah telah terjadi karena akibat orang percaya tidak mematuhi protokol kesehatan dalam proses melawan Corona. Salah satu penyebab ketidaktaatan dan ketidakpatuhan masyarakat terhadap kebijakan pemerintah baik dalam memberlakukan PPKM (Pemberlakuan Pembatasan Kegiatan Masyarakat) memberikan respons ketidakpedulian dan tidak efektif terhadap kesehatan diri sendiri, adalah adanya anggapan bahwa wabah ini hanya konspirasi. ${ }^{52}$ Namun ada juga keegoisan dan mementingkan diri sendiri yang menganggap tubuhnya kebal dari virus sehingga melanggar peraturan dan kebijakan pemerintah dan menjadi apatis terhadap informasi yang real tentang pandemi ini. Sesungguhnya kepatuhan masyarakat kepada pemerintah dalam masa pandemik Covid-19 adalah hal yang sangat diwajibkan. Pemerintah pusat, daerah dan seluruh lapisan masyarakat harusnya bahu-membahu dalam mengatasi virus Covid-19.

Sejatinya ada penderitaan dapat diatasi sekaligus ada juga yang tidak dapat diatasi. Penderitaan yang datang dari keburukan fisik (malum physicum), yaitu ketika tubuh mengalami rasa sakit karena suatu penyakit atau hal-hal yang menyakitkan, dapat diatasi dengan cara hidup sehat melalui memakan makanan sehat, berolah raga teratur, menghindari hal-hal yang berpotensi membahayakan keselamatan diri, dan

${ }^{48}$ Elvin Atmaja Hidayat, "Iman Di Tengah Penderitaan: Suatu Inspirasi Teologis-Biblis Kristiani," MELINTAS 32, no. 3 (September 6, 2017): 285,

http://journal.unpar.ac.id/index.php/melintas/article/view/2695.

${ }^{49}$ Ibid.

${ }^{50}$ Yohanes Yotham, "Iman Dan Akal Ditinjau Dari Perspektif Alkitab,” Jurnal Simpson: Jurnal Teologi dan Pendidikan Agama Kristen (2015).

${ }^{51}$ Pierre Teilhard de Chardin, The Phenomenon of Man (london: Collins, 1959), 51.

${ }^{52}$ Vallerry Monica Pahu, Sekplin A S Sekeon, and Fima L F G Langi, "Hubungan AntaraJumlah Kasus Covid-19 Dengan Tren Pencarian Geogle Terkait Covid-19 Di Sulawesi Utara," KESMAS 9, no. 7 (2020). 
sebagainya. Keburukan jenis ini dimengerti sebagai proses pembelajaran agar manusia berhati-hati dalam menjaga kesehatannya atau sebagai sanksi karena manusia lalai merawat tubuhnya sendiri. Sedangkan contoh penderitaan yang tidak dapat diatasi adalah ketika Yusuf mengalami penderitaan karena dibenci dan dijual oleh saudara-saudaranya, sehingga mengalami nasib sebagai orang asing, selain itu Yusuf harus menerima fitnahan dari istri Potifar di Mesir. Yusuf berkata, "Janganlah bersusah hati dan janganlah menyesali diri, karena kamu menjual aku ke sini, sebab untuk memelihara kehidupanlah Allah menyuruh aku mendahului kamu" (Kej. 45:5). ${ }^{53}$

\section{Allah Turut Bekerja dalam Penderitaan}

Dalam iman kekristenan seharusnya orang percaya menanggapi penderitaan manusia sebagai sarana untuk menimbulkan iman akan Yesus Kristus yang juga menderita sebagai wujud keterlibatan Allah dalam sejarah penderitaan manusia; selanjutnya penderitaan yang sama juga menumbuhkan iman. ${ }^{54}$ Manusia sebagai makhluk yang diberi kemampuan oleh Allah dalam bernalar diharuskan ikut berperan untuk bersama-sama mengerjakan karya pemeliharaan atas ciptaan Allah (Kej. 1: 28; Kej. 45:5; Kel. 4:11-12; 1Kor. 12:6; Ef. 1:11; Flp. 2:13). Tuhan juga bergerak aktif dalam pemeliharaan-Nya bersama manusia. Pemeliharaan Allah bukanlah konsep yang membawa kemalasan ciptaan-Nya untuk pasrah karena semua telah ditetapkan. Justru sebaliknya, pemeliharaan Allah menuntut manusia menjadi pribadi yang bekerja sama untuk membawa karya Allah itu dalam hidup manusia. Seharusnya di mana pun kekristenan hadir, keberadaannya tidak hanya sekadar berbicara kasih. Karena kalau hanya untuk berbicara kasih semua orang pun bisa, tidak perlu ia mengenal dan hidup di dalam Kristus. Tetapi setiap orang yang hidup di dalam Kristus telah mengalami kasih sejati yang Kristus berikan, maka kasih di sini terwujud dalam perbuatan, yang mencapai nilai tertinggi dan menjadi inspirasi ${ }^{55}$, bagi seluruh manusia dalam ikut andil dan bekerja sama dengan pemerintah melawan Covid-19, dengan menjadi contoh dan teladan dalam ketaatan memenuhi protokol kesehatan.

Memang tidak dipungkiri respons orang berbeda-beda dalam menghadapi penderitaan dan persoalan yang berat atau krisis kehidupan, namun acap kali orang percaya lalai untuk menemukan jawaban tentang tujuan hidupnya. Setiap orang memiliki peluang untuk memilih, yaitu memaknai penderitaan dalam hidupnya dari segi positif atau tidak memaknainya dengan memilih kehidupan yang hampa. Orang yang tidak memaknai kehidupannya secara positif bisa juga menyalahkan keadaan dan pribadi pencipta. Orang-orang yang menemukan arti hidup melalui penderitaan atau krisis yang dihadapi akan mengerti kedalaman tujuan hidupnya dan juga mengalami pemulihan yang mengubah hidupnya. ${ }^{56}$ Ini menjadikan kerohanian semakin berkua-

\footnotetext{
${ }^{53}$ Hidayat, "Iman Di Tengah Penderitaan: Suatu Inspirasi Teologis-Biblis Kristiani."

${ }^{54}$ Ibid.

${ }^{55}$ I Made Suardana, "Identitas Kristen Dalam Realitas Hidup Berbelaskasihan: Memaknai Kisah Orang Samaria Yang Murah Hati," Jurnal Jaffray 13, no. 1 (2015): 121.

${ }^{56}$ Rini Wulandari, "Pelayanan Pastoral Bagi Istri Yang Berduka Dan Signifikansinya Terhadap Proses Penemuan Makna Hidup Jemaat Gereja Kristen Jawa Kismorejo Karanganyar," Missio Ecclesiae Institut Injil Indonesia 8, no. 1 (2019): 17-44.
} 
litas dan membawa perubahan dalam pola pikir, sehingga keyakinan iman kepada Allah dikukuhkan dan dikuatkan kembali, sebab pribadi Allah yang transenden, Mahakuasa dan Mahabaik itu tidak acuh melihat penderitaan dan persoalan manusia di segala bidang umat manusia. Selain secara transenden, Allah bertindak secara imanen dan konkret di dalam Yesus Kristus untuk mendemonstrasikan kuasa-Nya, karena Allah memiliki sifat kasih yang besar bagi manusia, bahkan mengambil penderitaan manusia di dalam penderitaan dan kematian-Nya sendiri demi menyelamatkan mereka.

Dampak dari adanya Covid-19 tersebut juga menyebabkan perekonomian di Indonesia menjadi merosot, menjatuhkan nilai tukar rupiah, harga barang naik, dan dapat juga memicu konflik horizontal. ${ }^{57}$ Sehingga aspek ekonomi juga mengalami persoalan yang besar. Pemerintah telah melakukan pembatasan sosial atau menjaga jarak untuk mencegah penularan Covid-19 agar tidak menyebar luas di wilayah bangsa Indonesia. Diharapkan orang percaya dapat menaati social distancing, sebab hal ini sangat penting untuk menghambat penyebaran Covid-19.

Tidak sedikit orang mengalami kolaps dan bangkrut karena ujian dan tantangan yang terjadi di masa pandemi Covid-19 ini dapat mengintervensi orang percaya semakin setia atau sebaliknya. Memang jelas naluri kekhawatiran manusia terjadi saat kasat mata melihat persoalan namun sejatinya sebagai orang percaya tetap mengandalkan Tuhan bahwa Ia pasti memelihara karena Allah punya maksud dan tujuan yang baik ketika menciptakan dunia dengan mengizinkan adanya penderitaan, Dia sendiri pun turut bekerja di dalam segala sesuatu untuk menggenapi tujuan akhir yang telah direncanakan-Nya. Allah turut bekerja dalam segala sesuatu untuk mendatangkan kebaikan bagi mereka yang mengasihi Dia, yaitu bagi mereka yang terpanggil sesuai dengan rencana Allah (Rm. 8:28).

\section{KESIMPULAN}

Dapat disimpulkan bahwa wabah Covid-19 yang terjadi saat ini dapat menimpa siapa pun tanpa memandang bulu, karena itu orang percaya diharapkan untuk selalu mengandalkan Tuhan dan mematuhi aturan pemerintah. Perlindungan Allah yang dideskripsikan sebagai jaminan pemeliharaan Tuhan terjadi dalam masa Perjanjian Lama dan Perjanjian Baru menjadi acuan konsep pemeliharaan dan proteksi Tuhan di masa pandemi ini. Perlindungan Allah berlaku untuk kehidupan keseharian umat-Nya di dalam dunia yang penuh penderitaan. Jika Tuhan mengizinkan orang percaya masuk dalam penderitaan akibat pandemi Covid-19, pasti Allah memberi kekuatan untuk menanggung penderitaan itu. Jika Allah mengizinkan orang percaya meninggal karena Covid-19, itu juga adalah bentuk Perlindungan Allah dalam hal memelihara iman orang tersebut. Orang percaya masa kini diharapkan menjadi pribadi yang taat kepada Tuhan dengan cara taat kepada aturan yang dibuat pemerintah yang menjadi sarana untuk memelihara orang percaya dalam situasi pandemi Covid-19 yang mengganas.

${ }^{57}$ Ericha Windhiyana, "Dampak Covid-19 Terhadap Kegiatan Pembelajaran Online Di Perguruan Tinggi Kristen Di Indonesia,” Perspektif Ilmu Pendidikan 34, no. 1 (2020): 1-8. 
Penelitian tentang God's Protection ini dilakukan dalam hubungan dengan pandemi Covid-19 yang sedang terjadi. Penelitian dapat dikembangkan untuk segi-segi lain dalam hidup manusia yang sering dikaitkan dengan penderitaan, khususnya dalam kaitan dengan pelayanan pastoral, misalnya bagi penderita penyakit terminal atau kehilangan anggota keluarga.

\section{REFERENSI}

Agung, Ivan Muhammad. "Memahami Pandemi Covid-19 Dalam Perspektif Psikologi Sosial." Psikobuletin:Buletin Ilmiah Psikologi 1, no. 2 (2020): 68-84. http://ejournal.uinsuska.ac.id/index.php/Psikobuletin/article/view/9616/5058.

Alinurdin, David. “COVID-19 Dan Tumit Achilles Iman Kristen.” Veritas: Jurnal Teologi dan Pelayanan 19, no. 1 (2020): 1-9.

Alkitab Sabda. "Pemeliharaan Allah." Yayasan Lembaga SABDA (YLSA). Last modified 2005. Accessed September 23, 2020. https://alkitab.sabda.org/article.php?id=8404.

Arifianto, Yonatan Alex. "Pentingnya Pendidikan Kristen Dalam Membangun Kerohanian Keluarga Di Masa Pandemi Covid-19." Regula Fidei Jurnal Pendidikan Agama Kristen 5, no. 2 (2020): 94-106.

Baharudin, Iksan, Chairul, and Muhammad Abdi, Nur. "Ancaman Krisis Ekonomi Global Dari Dampak Penyebaran Virus Corona (Covid-19).” AkMen Jurnal Ilmiah (2020).

Bancin, Kerdi. "NASEHAT TENTANG KEKUATIRAN STUDI EKSEGETIS MATIUS 6: 2534 DAN REFLEKSINYA PADA KEHIDUPAN UMAT KRISTEN MASA KINI." Areopagus: Jurnal Pendidikan Dan Teologi Kristen 18, no. 2 (2020): 161-169.

Basthoumi Muslih. "Urgensi Komunikasi Dalam Menumbuhkan Motivasi Di Era Pandemi Covid-19." 58 Jurnal Penelitian Manajemen Terapan (PENATARAN) Vol. 5, no. 1 (2020): 57-65.

Bibleworks, BibleWorks ceased operation as a provider of. "BibleWorks," 2018.

Buana, Dana Riksa. "Analisis Perilaku Masyarakat Indonesia Dalam Menghadapi Pandemi Virus Corona (Covid-19) Dan Kiat Menjaga Kesejahteraan Jiwa." SALAM: Jurnal Sosial dan Budaya Syar-i 7, no. 3 (2020).

Casriarno, Adida, and Demianus Nataniel. "Dinamika Pendidikan Agama Kristen Di Tengah Wabah Corona: Sebuah Refleksi Berdasarkan Pengajaran Paulus Dalam Galatia 6:2." Jurnal Abdiel: Khazanah Pemikiran Teologi, Pendidikan Agama Kristen, dan Musik Gereja 4, no. 1 (2020): 25-42.

Chardin, Pierre Teilhard de. The Phenomenon of Man. london: Collins, 1959.

Drewes, B.F., Wilfrid Haubeck, and Siebenthal Heinrich Von. Kunci Bahasa Yunani Perjanjian Baru Surat Roma Hingga Kitab Wahyu,. Jakarta: BPK Gunung Mulia, 2011.

Hadiwardoyo, Wibowo. "Kerugian Ekonomi Nasional Akibat Pandemi Covid-19." Baskara Journal of Business and Enterpreneurship 2, no. 2 (2020): 83-92. https://jurnal.umj.ac.id/index.php/baskara/article/view/6207.

Hadiwijono, Harun. Iman Kristen. Jakarta: BPK Gunung Mulia, 2007.

Henry's Matthew. "Matthew Henry Commentary On Whole Bible." Last modified 2002. https://www.biblestudytools.com/commentaries/matthew-henrycomplete/Kisah Para Rasul/2.html. 
Hidayat, Elvin Atmaja. "Iman Di Tengah Penderitaan: Suatu Inspirasi Teologis-Biblis Kristiani.” MELINTAS 32, no. 3 (September 6, 2017): 285. http://journal.unpar.ac.id/index.php/melintas/article/view/2695.

Kementerian Kesehatan Republik Indonesia. "Pedoman Kesiapsiagaan Menghadapi Coronavirus Disease (COVID-19)." Direkorat Jenderal Pencegahan dan Pengendalian Penyakit (2020).

Khasanah, Dian Ratu Ayu Uswatun, Hascaryo Pramudibyanto, and Barokah Widuroyekti. "Pendidikan Dalam Masa Pandemi Covid-19." Jurnal Sinestesia 10, no. 1 (2020): 41-48. https://sinestesia.pustaka.my.id/journal/article/view/44.

Kosasih, Engkos, Agus Suyadi Raharusun, Reza Pahlevi Dalimunthe, and Aceng Abdul Kodir. "Literasi Media Sosial Dalam Pemasyarakatan Moderasi Beragama Dalam Situasi Pandemi Covid-19." Digital Library UIN Sunan Gunung Djati Bandung (2020).

Kusradi, Sri Wahyuni. "Kasih Setia Tuhan Dalam Perjanjian Lama Dan Relevansinya Bagi Orang Percaya Pada Masa Covid-19." SCRIPTA: Jurnal Teologi dan Pelayanan Kontekstual 9, no. 1 (2020): 53-71. https://ejournal.stte.ac.id/index.php/scripta/article/view/112.

Lukito, Daniel L. "Iman Kristen Di Tengah Pandemi: Hidup Realistis Ketika Penderitaan Dan Kematian Merebak.” LP2M STT SAAT, 2020.

Manik Pratiwi, Anak Agung. "Peran Media Sosial Dalam Meningkatkan Penjualan Online Saat Pandemi Covid-19." Jurnal Ilmiah Satyagraha 3, no. 2 (2020): 73-81.

Mondolu, Debby Christ, and Obet Nego. "Covid-19: Wabah Alkitabiah, Relevankah?" SCRIPTA: Jurnal Teologi dan Pelayanan Kontekstual 9, no. 1 (2020): 32-51.

Mulyana, Yusep. "Peranan Ekonomi Pembangunan Pasca Covid 19." PRISMAKOM Sekolah Tinggi Ilmu Ekonomi Yasa Anggana Garut 17, no. 1 (2020): 37-45.

Nurwati, Rahma Ainul Mardiya dan R. Nunung. "Dampak Pandemi Covid-19 Terhadap Peningkatan Angka Pengangguran Di Indonesia." Rahma Ainul Mardiyah R. Nunung Nurwati (2020).

Pahu, Vallerry Monica, Sekplin A S Sekeon, and Fima L F G Langi. "Hubungan AntaraJumlah Kasus Covid-19 Dengan Tren Pencarian Geogle Terkait Covid-19 Di Sulawesi Utara." KESMAS 9, no. 7 (2020).

Pradana, Whisnu. "Positif Corona Juga, Istri Pendeta Meninggal Di RSHS Bandung." DetikNews Berita Jawa Barat. Last modified 2020. Accessed September 22, 2020. https://news.detik.com/berita-jawa-barat/d-4956105/positif-coronajuga-istri-pendeta-meninggal-di-rshs-bandung.

Putri, Nabila Farahdila, Ellin Vionia, and Tomy Michael. "Masyarakat Indonesia Menghadapi Penyebaran Berita Hoax Covid-19." Jurnal Ilmu Hukum 11, no. 1 (2020): 98-111.

Regus, Max, and Marianus M. Tapung. "Penanganan Covid-19 Dalam Semangat Diakonia Gereja Keuskupan Ruteng: Sebuah Lapoan PKM." BERDAYA: Jurnal Pendidikan dan Pengabdian Kepada Masyarakat 2, no. 2 (2020): 41-52.

Satya, Putu Agung Nara Indra Prima. “Covid- 19 Dan Potensi Konflik Sosial.” Jurnal Ilmiah Hubungan Internasional 0, no. 0 (2020): 39-45.

Sitompul, Romianna Magdalena. "Makna Perkataan Paulus Tentang Hidup Adalah Kristus Dan Mati Adalah Keuntungan Berdasarkan Filipi 1:12-26." Jurnal Jaffray 15, no. 2 (2017): 153.

SJ, Darminta. Peziarahan Keluarga. Yogyakarta: kanisius, 2006. 
Suardana, I Made. "Identitas Kristen Dalam Realitas Hidup Berbelaskasihan: Memaknai Kisah Orang Samaria Yang Murah Hati." Jurnal Jaffray 13, no. 1 (2015): 121.

Susanto, Hasan. Konkordansi Pejanjian Baru Interlinear Yunani-Indonesia,. Jakarta: Lembaga Alkitab Indonesia, 2004.

Syafrida, Syafrida, and Ralang Hartati. "Bersama Melawan Virus Covid 19 Di Indonesia." SALAM: Jurnal Sosial dan Budaya Syar-i 7, no. 6 (2020): 495-508.

Tuhumury, Hanok. "Pelayanan Pastoral Konseling Berdasarkan 1 Petrus 5:1-11." Missio Ecclesiae 7, no. 1 (2018): 68-100.

Wilkinson Bruce, and Boa kenneth. The Talk Thru Bible. Malang: Gandum Mas, 2017.

Windhiyana, Ericha. "Dampak Covid-19 Terhadap Kegiatan Pembelajaran Online Di Perguruan Tinggi Kristen Di Indonesia.” Perspektif Ilmu Pendidikan 34, no. 1 (2020): 1-8.

Wulandari, Rini. "Pelayanan Pastoral Bagi Istri Yang Berduka Dan Signifikansinya Terhadap Proses Penemuan Makna Hidup Jemaat Gereja Kristen Jawa Kismorejo Karanganyar." Missio Ecclesiae Institut Injil Indonesia 8, no. 1 (2019): 17-44.

Yotham, Yohanes. “Iman Dan Akal Ditinjau Dari Perspektif Alkitab.” Jurnal Simpson: Jurnal Teologi dan Pendidikan Agama Kristen (2015).

Zaluchu, Sonny Eli. "Strategi Penelitian Kualitatif Dan Kuantitatif Di Dalam Penelitian Agama." Evangelikal: Jurnal Teologi Injili dan Pembinaan Warga Jemaat 4, no. 1 (2020): 28.

"The Wycliffe Bible Commentary." Biblestudytoolscom. Last modified 2014. Accessed June 30, 2020. https://www.biblestudytools.com/wyc/. 